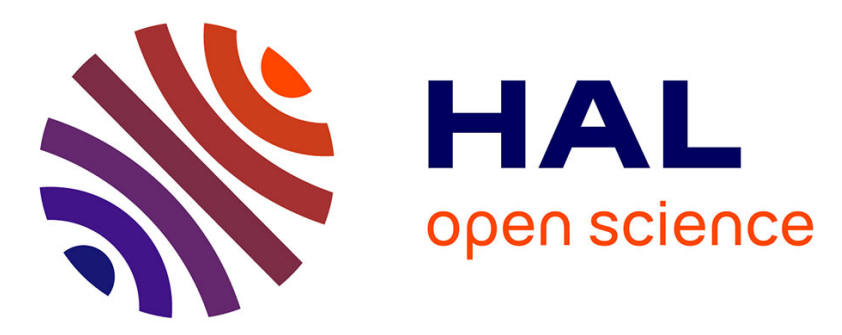

\title{
FURTHER DEVELOPMENT OF THE QUALITATIVE ELLIPSOMETRIC TECHNIQUE FOR THE STUDY OF CORROSION PROCESSES UNDER ORGANIC COATINGS
}

\author{
J. Ritter, J. Kruger
}

\section{To cite this version:}

J. Ritter, J. Kruger. FURTHER DEVELOPMENT OF THE QUALITATIVE ELLIPSOMETRIC TECHNIQUE FOR THE STUDY OF CORROSION PROCESSES UNDER ORGANIC COATINGS. Journal de Physique Colloques, 1983, 44 (C10), pp.C10-225-C10-228. 10.1051/jphyscol:19831047 . jpa-00223504

\section{HAL Id: jpa-00223504 https://hal.science/jpa-00223504}

Submitted on 1 Jan 1983

HAL is a multi-disciplinary open access archive for the deposit and dissemination of scientific research documents, whether they are published or not. The documents may come from teaching and research institutions in France or abroad, or from public or private research centers.
L'archive ouverte pluridisciplinaire HAL, est destinée au dépôt et à la diffusion de documents scientifiques de niveau recherche, publiés ou non, émanant des établissements d'enseignement et de recherche français ou étrangers, des laboratoires publics ou privés. 


\title{
FURTHER DEVELOPMENT OF THE QUALITATIVE ELLIPSOMETRIC TECHNIQUE FOR THE STUDY OF CORROSION PROCESSES UNDER ORGANIC COATINGS
}

\author{
J.J. Ritter and J. Kruger \\ Center for Materials Science, National Bureau of Standards, Washington, \\ DC 20234, U.S.A.
}

\begin{abstract}
Résumé - On décrit un nouveau dêveloppement d'une technique eliipsométrique utîtisée pour étudier les processus de corrosion sous revêtements organiques. Ce développement permet de détecter l'influence de différents revêtements organiques, de distinguer entre l'apparition de rugosité et la croissance d'un film ou sa dissolution, enfin d'étudier le processus de corrosion se produisant sur des sites anodiques et cathodiques séparés.
\end{abstract}

Abstract - We describe the further development of an ellipsometric technique used to study corrosion processes under organic coatings. These developments include the ability to (1) detect the effect of different organic coating, (2) distinguish between surface roughening and film growth or dissolution, and (3) study corrosion processes occurring on separate anodic and cathodic sites.

The qualitative ellipsometric technique developed for the study of corrosion processes under organic coatings described at the International Conference on Ellipsometry held in Berkeley, California has been refined and extended. These new developments which will be described in this paper are the following. (1) the demonstration that the ellipsometer is capable of revealing the effect of using different organic coatings; (2) the development of an ellipsometric method to distinguish between surface roughening and $f i l m$ growth or dissolution processes occurring under organic coatings and (3) the development of a segmented specimen technique that allows an ellipsometric study of the separate anodic and cathodic areas that form under an organic coating.

\section{Studying the Effect of Organic Coating Type}

Previous studies $(1,2)$ applying ellipsometry to the investigation of corrosion processes under organic coating have utilized air-cured collodion (cellulose dinitrate), assuming that the nature of the transparent organic coating would not have a significant effect on the change of the ellipsometric parameters, $\Delta$ and $\psi$, during the early stages of the corrosion processes occurring under the coatings. As Figs. la and b show, this is not so. Indeed, both the nature of the polymer constituting the coating and the temperature of the cure (heat treatment) strongly influence the changes in $\Delta$ with time when the coated metal is immersed in an aqueaus electrolyte. The interpretation of $\mathrm{Fig}$. la (the air cured room temperature coatings) is given in Fig. 2 and discussed in the next section. When the coatings are cured in air at an elevated temperature $\left(200^{\circ} \mathrm{C}\right)$, it is more difficult to give a detailed interpretation. The large rise in $\Delta$ at the beginning of the corrosion process is probably due to the dissolution of a rather thick oxide film $(\sim 14 \mathrm{n} \mathrm{m})$ formed during the curing process of $200^{\circ} \mathrm{C}$. The events beyond the initial sharp rise in $\Delta$ are more difficult to interpret. A more detailed discussion is given by Ritter $/ 3 /$. 


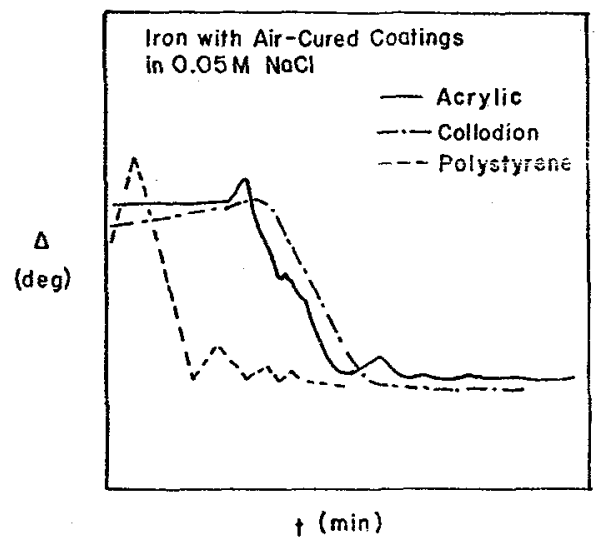

Fig. 1a - Variation of $\Delta$ with time for three iron/coating systems undergoing corrosion in an aqueous chloride solution. The coatings shown were cured in air at room temperature.

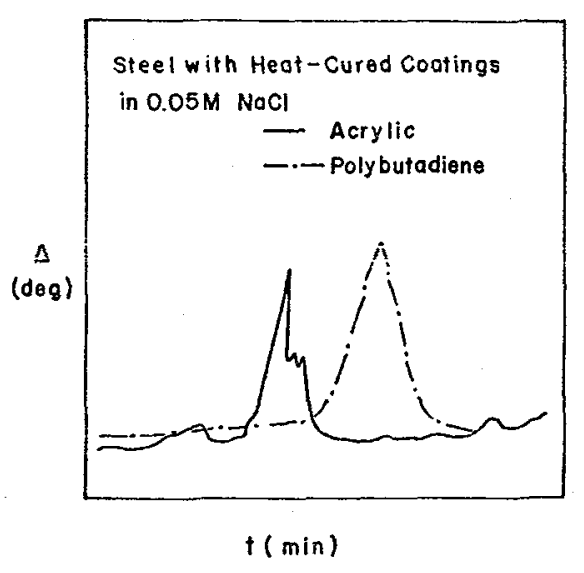

Fig. 1b - Same as Fig. la but the coatings were cured in air at $200^{\circ} \mathrm{C}$

Distinguishing between Roughening and $\mathrm{Fi} I \mathrm{~m}$ Growth or Dissolution

Fig. 2 shows $\Delta$ and $\psi$ plots vs. time obtained using an automatic ellipsometer for an iron surface coated with a room temperature air-cured acrylic undergoing corrosion in $0.05 \mathrm{M} \mathrm{NaCl}$ solution. Three regions can be delineated. The significance of these regions are described in Fig. 2. It can be seen in Fig. 2 that when $d \Delta / d t$ and $d \psi / d t$ have the same sign surface roughening or surface smoothing the coated iron to taking place; when $d \Delta / d t$ and $d \psi / d t$ have opposite signs, film growth or dissolution occurring.

This interpretation of the behavior of $\Delta$ and $\psi$ is based on our observations of uncoated iron in a buffered solution after carrying out potential cycling, a process which produces a smoother surface. More details are given in an earlier paper $/ 2 /$.

\section{Observing Corrosion Processes at Anodic and Cathodic Sites}

Fig. 3a shows the arrangement developed by Ritter /3/ for studying the spatial development of subcoating cathodes and anodes using the ellipsometer. By puncturing one segment of the segmented specimen, one can promote the immediate formation of an anode on that specimen. This procedure then allows one to follow the real time development of cathodes on the unpunctured segment.

Fig. 3b gives the variation of $\Delta$ and $\mathrm{pH}$ (an important parameter in subcoating corrosion) with time for the anodic ("a") and cathodic ("c") segments. During the first 1400 min before the coating is punctured, there is little change in $\Delta$ for both segments. The pH varies between 5 and 8 . When the segment "a" is punctured at 1400 min, thereby making it 


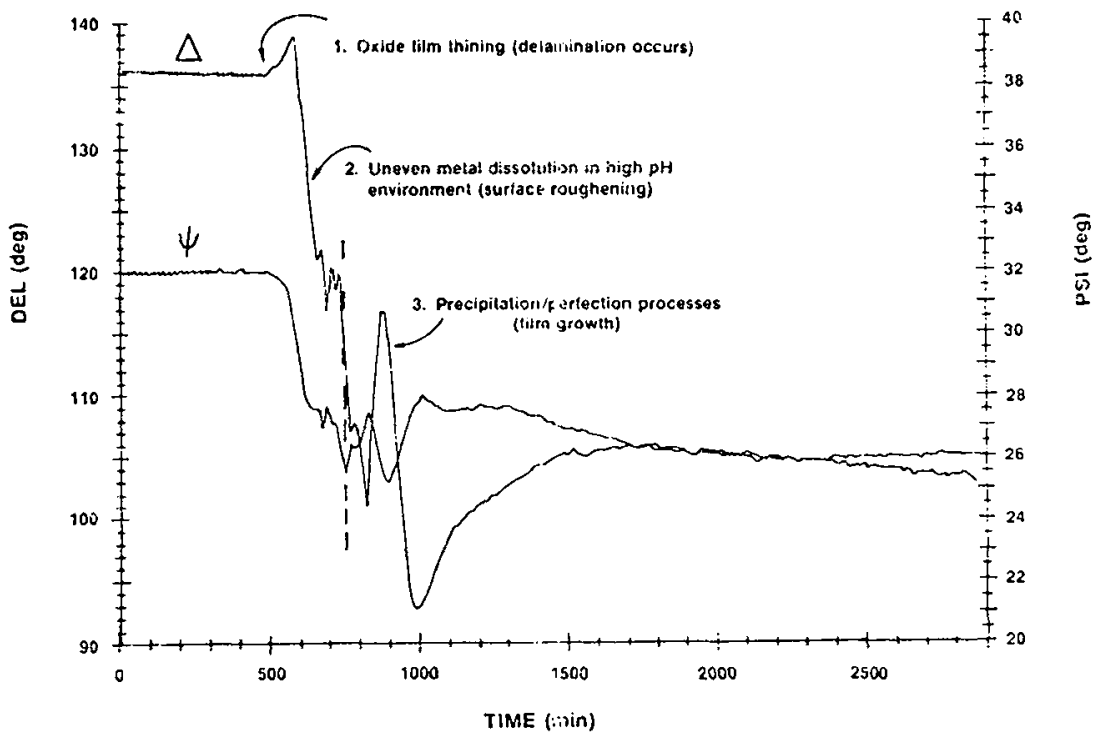

Fig. 2 - $\Delta$ and $\psi$ plots vs. time made using an automatic ellipsometer for an iron/acrylic coating system undergoing corrosion in $0.05 \mathrm{M} \mathrm{NaCl}$ solution.

the anode, a significant rise in $\Delta$ is observed. If the seyments " $a$ " and " $c$ " are connected by joining the copper wire conductors attached to each (shown in $\mathrm{Fig}$. 3a), the $\mathrm{pH}$ on "c" rises to about 13.5 and the $\Delta$ measured for " $c$ " by the ellipsometer remains relatively constant. The chanye in $\Delta$ found for "a" however, is similar to that shown in Regions I and II in Fig. 2. When the conducting wires to "a" and " $c$ " are disconnected, the subcoating $\mathrm{pH}$ drops to 8 in a few minutes. Reconnecting brings the $\mathrm{pH}$ back to 13 within $b$ min. If the anodic and cathodic segments are left coupled for a few days, the subcoating $\mu \mathrm{H}$ on "c" declines, $\Delta$ for "a" decreases markedly while $\Delta$ for "c" also goes down but not as much.

A detailed discussion of the meaning of these results in terms of corrosion processes under coatings is given by Ritter in an earlier publication $/ 3 /$.

\section{Summary}

1. It has been established that the ellipsometer is capable of revealing the effect of different organic coatings on the subcoating corrosion proceses.

2. Using an automated ellipsometer, it has been demonstrated for the iron systems studied that when $d \Delta / d t$ and $d \psi / d t$ have opposite signs, corrosion product films are growing or dissolving and when they have the same sign, surface is becomming smoother or rougher.

Thus, surface roughening surface smoothing and film growth processes or dissolution can be identified. 


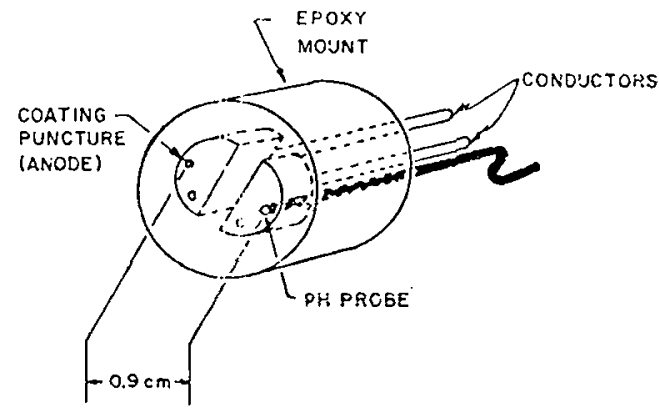

Fig. 3a - The segmented specimen that allows the ellipsonetric examination of the development of anodic ("a") and cathodic ("c") sites on coated iron.

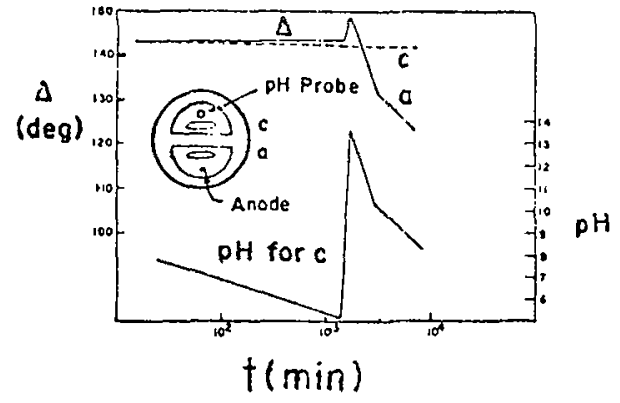

Fic. $3 b-\Delta, \psi$ and $p H$ plotted vs time for a seymented iron/acrylic system in $0.05 \mathrm{M} \mathrm{NaCI}$ solution. Inset shows the arrangement on the surface of the specimen, the ellipses shown being the regions studied ellipsometrically.

3. A segmented specimen has been developed that allows ellipsometric study of separate anodic and cathodic areas that form under an organic coating.

\section{Acknowledgement}

The authors are yrateful to the Uffice of Naval Research who partially supported this work under contract No. NAONR 18-69. NRO 36-082

\section{References}

/1/ RITTEK, J.d, and KRUGER, J., Surf. SCi. 96 (1980) 364.

/2/ RITTER, J.J. and KRUGEK, J., Corrosion Contral by Organic Coatings, H. Leidheiser, Jr., Ed., (National Association of Corrosion Engineers, Houston, $T X) 1981$, p. 28.

/3/ RITTER, J.J., J. Coatings Technology 34 (1982) bl. 